\title{
Metabolic Abnormalities, Dietary Risk Factors and Nutritional Management in Amyotrophic Lateral Sclerosis
}

\author{
Emanuele D'Amico ${ }^{1}\left(\mathbb{D}\right.$, Giuseppe Grosso ${ }^{2, *(\mathbb{D}}$, Jeri W. Nieves ${ }^{3}{ }^{(\mathbb{C}}$, Aurora Zanghì ${ }^{1}$, Pam Factor-Litvak ${ }^{3}$ \\ and Hiroshi Mitsumoto ${ }^{4}$ \\ 1 Department G.F. Ingrassia, University of Catania, 95123 Catania, Italy; emanuele.damico@unict.it (E.D.); \\ aurora.zanghi@yahoo.it (A.Z.) \\ 2 Department of Biomedical and Biotechnological Sciences, University of Catania, 95123 Catania, Italy \\ 3 Mailman School of Public Health and Institute of Human Nutrition, Columbia University, \\ New York, NY 10032, USA; jwn5@cumc.columbia.edu (J.W.N.); prf1@cumc.columbia.edu (P.F.-L.) \\ 4 Eleanor and Lou Gehrig ALS Center, The Neurological Institute of New York Columbia University Medical \\ Center, New York, NY 10032, USA; hm264@cumc.columbia.edu \\ * Correspondence: giuseppe.grosso@unict.it; Tel.: +39-0954-781-187
}

Citation: D'Amico, E.; Grosso, G.;

Nieves, J.W.; Zanghì, A.;

Factor-Litvak, P.; Mitsumoto, H. Metabolic Abnormalities, Dietary Risk Factors and Nutritional Management in Amyotrophic Lateral Sclerosis. Nutrients 2021, 13, 2273. https://doi.org/10.3390/nu13072273

Academic Editor: Elisabet Børsheim

Received: 25 March 2021

Accepted: 28 June 2021

Published: 30 June 2021

Publisher's Note: MDPI stays neutral with regard to jurisdictional claims in published maps and institutional affiliations.

Copyright: (c) 2021 by the authors. Licensee MDPI, Basel, Switzerland. This article is an open access article distributed under the terms and conditions of the Creative Commons Attribution (CC BY) license (https:// creativecommons.org/licenses/by/ $4.0 /)$.

\begin{abstract}
Amyotrophic Lateral Sclerosis (ALS) is a devastating progressive neurodegenerative disease that affects motor neurons, leading to a relentless paralysis of skeletal muscles and eventual respiratory failure. Although a small percentage of patients may have a longer survival time (up to 10 years), in most cases, the median survival time is from 20 to 48 months. The pathogenesis and risk factors for ALS are still unclear: among the various aspects taken into consideration, metabolic abnormalities and nutritional factors have been the focus of recent interests. Although there are no consistent findings regarding prior type-2 diabetes, hypercholesterolemia and ALS incidence, abnormalities in lipid and glucose metabolism may be linked to disease progression, leading to a relatively longer survival (probably as a result of counteract malnutrition and cachexia in the advanced stages of the disease). Among potential dietary risk factors, a higher risk of ALS has been associated with an increased intake of glutamate, while the consumption of antioxidant and antiinflammatory compounds, such as vitamin E, n-3 polyunsaturated fatty acids, and carotenoids, has been related to lower incidence. Poor nutritional status and weight loss in ALS resulting from poor oral intake, progressive muscle atrophy, and the potential hypermetabolic state have been associated with rapid disease progression. It seems important to routinely perform a nutritional assessment of ALS patients at the earliest referral: weight maintenance (if adequate) or gain (if underweight) is suggested from the scientific literature; evidence of improved diet quality (in terms of nutrients and limits for pro-inflammatory dietary factors) and glucose and lipid control is yet to be confirmed, but it is advised. Further research is warranted to better understand the role of nutrition and the underlying metabolic abnormalities in ALS, and their contribution to the pathogenic mechanisms leading to ALS initiation and progression.
\end{abstract}

Keywords: amyotrophic lateral sclerosis; neurons; glucose metabolism; lipid metabolism; obesity; metabolic disorders; energy expenditure; dietary factors; malnutrition; comprehensive review

\section{Introduction}

Amyotrophic lateral sclerosis (ALS) is a neurodegenerative disease characterized by the degeneration of lower and upper motor neurons, which leads to progressive skeletal muscle atrophy, paralysis, and consequent death, usually with a 48-month medium survival after symptom onset [1]. The ALS affects approximately two individuals per 100,000 each year, with a prevalence of about seven individuals per 100,000. Males are slightly more affected than females (ratio of about 1.6:1) [2]. As clinical phenotypes are markedly heterogeneous, ALS started to be considered as a "syndrome" rather than a single nosological condition [3]. While most ALS cases (more than 90\%) are sporadic, from 
approximately 5 to 10 percent of all ALS are related to multigenic traits [4]; however, the overall genetic background of the disease is only partly understood.

Putative disease mechanisms include several cellular changes, starting with neuroinflammation and oxidative damage, leading to mitochondrial dysfunction, the accumulation of intracellular protein aggregates, impairment of axonal transport, growth factor abnormalities, glutamate excitotoxicity, etc. [5]. Among the potential risk factors, a host of environmental factors were considered [6]. Moreover, emerging evidence suggests that the microbiome may be linked to neurodegenerative diseases, and directly related to nutrition and energy metabolism [7], and, interestingly, an alteration in the microbiome profile was shown in ALS patients [8]. Although the pathological changes characterizing the abnormalities in ALS were considered to only affect motor neurons, it appears that the wider involvement of the central nervous system (CNS), such as the frontotemporal lobar degeneration (FTLD) and pseudobulbar affect, as well as the implication of other districts, such as the skin, bone, gastrointestinal, and immune system, may occur [9]. This broader involvement could explain the vast diversity of the neuropathological and clinical phenotypes associated with ALS, raising the necessity of considering all the systemic effects of the disease when formulating the therapeutic interventions [10,11].

Since its approval in December 1995, Riluzole, an anti-glutamate agent able to extend the survival of ALS patients by a few months, has remained the only treatment [12]. In 2017, the second drug approved by the US Food and Drug Administration (FDA) edaravone was an antioxidant free-radical scavenger; however, it has not been approved by European Medicine Agency (EMA). A study on Japanese patients receiving it revealed that they declined less rapidly than those receiving a placebo, as measured by the change in the revised ALS Functional Rating Scale (ALSFRS-R) score after 24 weeks of treatment following an untreated 12-week lead-in [13]. However, another three trials on edaravone reported adverse outcomes [14]. Furthermore, it has antithrombotic and thrombolytic properties, and its relative benefit might reflect the mitigation of infusion-related thrombosis [15]. Although it is possible to better manage patients with ALS than before [16-18], disease-modifying medications have been severely limited.

Evidence suggests that ALS patients may suffer from an abnormal energy metabolism, as well as an impaired glucose and lipid metabolism [19-21]. Furthermore, body weight and body mass index (BMI) have been hypothesized to play a role in disease occurrence and progression in ALS [22]. Diet has been shown to potentially play a role in less disruptive mental health disorders [23], but there is a growing interest in exploring the potential role of nutritional and metabolic factors in affecting the survival of ALS patients [24]. The aim of this study is to review the current evidence on the role of metabolism and nutrition in the etiology and prognosis of ALS on human subjects.

\section{Metabolic Changes in ALS}

Metabolic abnormalities, including dyslipidemia and glucose intolerance, have often been reported in patients with ongoing ALS [25] and pre-morbid conditions [26]. However, it is unclear whether the metabolic changes found in ALS patients only arise as a result of neurodegeneration or whether they might play a role in the pathogenesis of the disease [21].

\subsection{Glucose Metabolism in ALS}

Earlier studies reported no difference $[27,28]$ or higher basal insulin levels in ALS compared to control patients [29]. In the last decade, new evidence relating type-2 diabetes mellitus (T2DM) and ALS has been reported [30]. In a large clinical cohort $(n=2371)$, T2DM was associated with lower risk of developing ALS [31,32]; moreover, in those patients where ALS developed, a delay of 4 years in the onset of the disease was observed [33]. Since then, several studies have confirmed a potential protective role of T2DM in ALS in terms of delayed onset $[34,35]$ and increased survival with T2DM [36], although the findings are not entirely consistent $[37,38]$. Another study investigating pre-morbid glucose abnormalities in ALS patients showed that the occurrence of insulin-dependent type-1 diabetes was 
associated with a higher risk of ALS in younger individuals, while T2DM was inversely associated with risk of ALS in older ones [39]; it has been hypothesized that genetic differences and lifelong medications may play a role, although the exact mechanisms are unclear [40].

There is evidence of impairment in the glucose-metabolizing pathways in ALS [41], such as decreased glucose consumption in the frontal lobe and cortex of patients with ALS [42,43]. Deficits in the insulin-mitochondrial axis could help explain the glucose metabolism abnormalities that have been described in ALS patients (see Table 1). The abnormal glucose intolerance in ALS could be secondary to muscle wasting or physical inactivity in ALS [44]. Another possibility is that there may be a decreased ability to store and/or mobilize loaded glucose in muscle [45]. Hyperlipidemia, also described in ALS, may also modulate glucose metabolism [46]. 
Table 1. Case series and case-control studies investigating lipid and glucose metabolism in ALS.

\begin{tabular}{|c|c|c|c|c|}
\hline Authors, and Date of Publication & Study Design & Number of ALS/Controls & $\begin{array}{l}\text { Most Important Lipids and Glucose } \\
\text { Laboratory Values Considered }\end{array}$ & Main Findings \\
\hline Gustafson, 1972 [47] & Case-control & $63 / 76 \mathrm{HC}$ & $\begin{array}{l}\text { Serum cholesterol, triglycerides, serum } \\
\text { lipoprotein patterns }\end{array}$ & $\begin{array}{l}\text { Hypercholesterolemia and hypertriglyceridemia } \\
\text { in } 27 \% \text { and } 10 \% \text { of ALS, respectively. }\end{array}$ \\
\hline Harno, 1984 [29] & Case-control & $21 / 10 \mathrm{OND}$ & OGTT, insulin levels, insulin resistance & $\begin{array}{l}\text { Higher basal insulin levels in ALS than in } \\
\text { controls }(p<0.05) \text {, but no difference after OGTT. }\end{array}$ \\
\hline Reyes 1984 [27] & Case-control & $10 / 15 \mathrm{HC} / 4 \mathrm{OND}$ & OGTT, insulin levels and resistance & $\begin{array}{l}\text { No difference in terms of IGT. Insulin resistance } \\
\text { in ALS vs. two groups }(p<0.001) \text {. }\end{array}$ \\
\hline Dupuis, 2008 [48] & Case-control & $369 / 286 \mathrm{HC}$ & $\begin{array}{l}\text { Serum cholesterol, triglycerides, HDL, } \\
\text { LDL, and LDL/HDL ratio }\end{array}$ & $\begin{array}{l}\text { Higher cholesterol, triglycerides, LDL and } \\
\text { LDL/HDL ratio in ALS patients than controls } \\
\text { ( } p<0.001) \text {. Longer survival (by } \sim 12 \text { months) in } \\
\text { ALS with high LDL/HDL ratio vs. low } \\
\text { LDL/HDL }(p<0.05) \text {. }\end{array}$ \\
\hline Chio', 2009 [49] & Case-control & $658 / 658 \mathrm{HC}$ & $\begin{array}{l}\text { Serum cholesterol, triglycerides, HDL, } \\
\text { LDL, and LDL/HDL ratio }\end{array}$ & $\begin{array}{l}\text { No differences ALS vs. controls. Total cholesterol, } \\
\text { LDL/HDL ratio, and triglycerides levels showed } \\
\text { a significant decrease in patients with FVC }<70 \% \\
\text { vs. FVC } \geq 90 \%(p<0.05) .\end{array}$ \\
\hline Pradat, 2010 [46] & Case-control & $21 / 21 \mathrm{HC}$ & $\begin{array}{l}\text { OGTT, insulin levels, serum cholesterol, } \\
\text { triglycerides, HDL, LDL, FFAs, TNF- } \alpha \\
\text { and IL-6, leptin and adiponectin }\end{array}$ & $\begin{array}{l}\text { At } 120 \text { min blood glucose was higher in ALS vs. } \\
\text { controls }(p=0.006) \text {. Insulin levels were increased } \\
\text { in ALS patients with IGT vs. no IGT patients at } \\
60 \text { and } 90 \text { min after glucose load ( } p=0.045 \text { and } \\
p=0.044 \text {, respectively). FFA levels were higher in } \\
\text { patients with IGT vs. no IGT ( } p=0.04) \text {. IGT was } \\
\text { not associated with disease duration or severity. }\end{array}$ \\
\hline Dorst, [50] & $\begin{array}{l}\text { Retrospective database } \\
\text { study }\end{array}$ & $488 /-$ & $\begin{array}{l}\text { Serum cholesterol, triglycerides, LDL, } \\
\text { HDL, LDL/HDL ratio }\end{array}$ & $\begin{array}{l}\text { Hypertriglyceridemia was associated with longer } \\
\text { survival (14 months } p=0.006) . \\
\text { Hypercholesterolemia was associated with } \\
\text { longer survival (11 months, } p=0.047) \text {. }\end{array}$ \\
\hline
\end{tabular}


Table 1. Cont.

\begin{tabular}{|c|c|c|c|c|}
\hline Authors, and Date of Publication & Study Design & Number of ALS/Controls & $\begin{array}{l}\text { Most Important Lipids and Glucose } \\
\text { Laboratory Values Considered }\end{array}$ & Main Findings \\
\hline Sutedja, 2011 [51] & Case-control & $303 / 2100 \mathrm{HC}$ & $\begin{array}{l}\text { Serum cholesterol, triglycerides, LDL, } \\
\text { HDL, LDL/HDL ratio }\end{array}$ & $\begin{array}{l}\text { In ALS less use of cholesterol-lowering drugs } \\
(p=0.008), \text { lower BMI }(p=0.001), \text { lower } \\
\text { LDL/HDL ratio (women: } p<0.001 ; \text { men: } \\
p<0.001) \text { in ALS. Cholesterol and LDL were } \\
\text { lower in patients with FVC }<70 \%(p<0.05) \text {. No } \\
\text { correlation hyperlipidemia with survival. }\end{array}$ \\
\hline Paganoni, 2011 [52] & $\begin{array}{l}\text { Retrospective database } \\
\text { study }\end{array}$ & $427 /-$ & $\begin{array}{l}\text { Serum cholesterol, triglycerides, LDL, } \\
\text { HDL, LDL/HDL ratio }\end{array}$ & $\begin{array}{l}\text { Hyperlipidemia was not associated with } \\
\text { increased survival. }\end{array}$ \\
\hline Ikeda, 2012 [53] & Case-control & $92 / 92$ & $\begin{array}{l}\text { Serum cholesterol, triglycerides, LDL, } \\
\text { HDL, LDL/HDL ratio, fasting } \\
\text { blood sugar }\end{array}$ & $\begin{array}{l}\text { Women with ALS had increased levels of } \\
\text { cholesterol }(p<0.05), \text { LDL }(p<0.01) \text {, and } \\
\text { triglycerides }(p<0.01) \text {. The annual decline in } \\
\text { ALS-FRS and FVC was inversely correlated with } \\
\text { baseline levels of cholesterol }(p<0.001) \text { and LDL } \\
\qquad(p<0.001) .\end{array}$ \\
\hline Dedic, 2012 [54] & $\begin{array}{l}\text { Retrospective database } \\
\text { study }\end{array}$ & $82 /-$ & $\begin{array}{l}\text { Serum cholesterol, triglycerides, LDL, } \\
\text { HDL, LDL/HDL ratio }\end{array}$ & $\begin{array}{l}\text { Hyperlipidemia was not associated with } \\
\text { increased survival. }\end{array}$ \\
\hline Huang, 2015 [56] & Case-control & $413 / 400$ & $\begin{array}{l}\text { Serum cholesterol, LDL, HDL, } \\
\text { triglycerides }\end{array}$ & $\begin{array}{l}\text { Longer life expectancy (median } 5.8 \text { months) in } \\
\text { ALS patients with higher triglyceride levels } \\
\qquad(>127.5 \mathrm{mg} / \mathrm{dl}) .\end{array}$ \\
\hline Mandrioli, 2017 [57] & $\begin{array}{l}\text { Retrospective cohort } \\
\text { study }\end{array}$ & $275 /-$ & $\begin{array}{l}\text { Serum cholesterol, triglycerides, LDL, } \\
\text { HDL, LDL/HDL ratio, glucose, ferritin, } \\
\text { albumin, creatinine }\end{array}$ & $\begin{array}{l}\text { Triglycerides were inversely associated with the } \\
\text { odds of death or tracheostomy }(p<0.05) \text {. }\end{array}$ \\
\hline
\end{tabular}


Table 1. Cont.

\begin{tabular}{|c|c|c|c|c|}
\hline Authors, and Date of Publication & Study Design & Number of ALS/Controls & $\begin{array}{l}\text { Most Important Lipids and Glucose } \\
\text { Laboratory Values Considered }\end{array}$ & Main Findings \\
\hline Wei, 2017 [38] & $\begin{array}{l}\text { Prospective cohort } \\
\text { study }\end{array}$ & $450 /-$ & fasting $\mathrm{HbA} 1 \mathrm{c}$ and glucose & $\begin{array}{l}\text { ALS with higher baseline HbA1c had } \\
\text { significantly higher risks of mortality }(p<0.001) \text {. }\end{array}$ \\
\hline Mariosa, 2017 [32] & $\begin{array}{l}\text { Population cohort } \\
\text { study }\end{array}$ & $623 / 15,575$ & $\begin{array}{l}\text { Serum glucose, serum cholesterol, } \\
\text { triglycerides, apoB and apoA-I, LDL } \\
\text { and HDL }\end{array}$ & $\begin{array}{c}\text { Increase in LDL }(p<0.001) \text {, apoB }(p<0.001) \text {, and } \\
\text { apoB / apoA-I ratio }(p<0.001) \text { was associated } \\
\text { with a higher incidence of ALS. High glucose } \\
\text { level }(\geq 6.11 \mathrm{mmol} / \mathrm{L}) \text { was associated with a } \\
\text { lower incidence }(p<0.001) .\end{array}$ \\
\hline Delaye, 2017 [58] & Case-control & $30 / 30$ & $\begin{array}{l}\text { Serum cholesterol, } 11 \text { distinct } \\
\text { lipoprotein subclasses }\end{array}$ & $\begin{array}{l}\text { Higher total cholesterol, HDL, and LDL levels in } \\
\text { ALS patients than controls }(p<0.001, p<0.001 \text {, } \\
\text { and } p=0.0065 \text {, respectively). }\end{array}$ \\
\hline Ingre, 2020 [59] & Cohort study & 99 & Cholesterol, lipoproteins & $\begin{array}{c}\text { Increase in total cholesterol }(p=0.01), \mathrm{LDL} \\
(p=0.02), \mathrm{LDL}: \text { HDL ratio }(p=0.02) \\
\text { apolipoprotein B }(p=0.01) \text {, or apolipoprotein } \\
\text { B/apolipoprotein AI ratio }(p<0.01) \text { was } \\
\text { associated with a lower risk of death in } \\
\text { ASL patients. }\end{array}$ \\
\hline
\end{tabular}

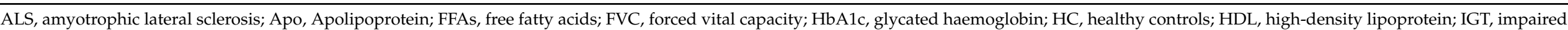
glucose tolerance; IL-6, interleukin-6; LDL, low-density lipoprotein; OND, other neurological diseases; OGTT, oral glucose tolerance test; TNF- $\alpha$, tumor necrosis factor-alpha. 
The metabolism of the energetic substrates (glucose and lipids) is closely related to the distribution of fat in the human body, and increased visceral fat is associated with T2DM, dyslipidemia and insulin resistance [60]. Earlier studies on adipose tissue in ALS patients focused on an analysis of fat mass (FM) using bioelectrical impedance analysis, showing that a decrease in fat-free mass was associated with adverse outcomes (including shorter survival) regardless of weight loss [61-63]. In a study using Magnetic Resonance Imaging (MRI)-based methodologies involving 62 ALS patients and matched controls, the distribution of total FM appeared to be roughly similar between groups, but ALS patients had expanded visceral fat and a higher visceral to subcutaneous fat ratio compared to the control [64].

Energy balance involves many other components, such as endocrine hormones (e.g., thyroid hormones, insulin/glucagon system, growth factor), but none of these were found to be abnormal in ALS $[65,66]$. Overall, glucose metabolism seems to be altered in ALS patients, but these abnormalities are not constantly observed in all patients [67-69]. Thus, these abnormalities cannot be consistently used as independent predictors of ALS prognosis.

\subsection{Lipid Metabolism}

The CNS is characterized by the variety and amount of lipids necessary to control membrane fluidity and the transmission of electrical impulses, and serve as precursors for second messengers [70]. Moreover, they are considered crucial to maintain the motor neuron functionality, with alterations in their homeostasis leading to potential neurodegenerative diseases [71].

The role of lipids in ALS prognosis is still unclear and the findings are rather conflicting [72]. Older studies showed alterations in circulating blood cholesterol (and related lipoprotein particles) and triglycerides over the course of ALS [47]. In a study conducted on 369 patients with ALS compared to a matched healthy control group, the frequency of hyperlipidemia (increased plasma levels of total and low-density lipoprotein (LDL) cholesterol), was more frequently observed in ALS patients than in control subjects [48]. In contrast, another study showed that the serum cholesterol and LDL/HDL ratio were significantly lower in controls than in ASL patients [55], and that baseline levels of cholesterol and LDL were inversely correlated with declined functionality in ALS patients [53]. Lipid alterations were also investigated in patients with ALS with or without cognitive and behavioral change (with the criteria of Frontotemporal Dementia (FTD)) [73]. In a case-control study of 128 participants, including 96 ALS patients and 32 healthy controls, an increased triglycerides $(p<0.001)$, total cholesterol/HDL ratio $(p<0.001)$, and lower HDL levels $(p=0.001)$ were observed in the cases group compared to the controls; moreover, a higher cholesterol level was associated with 3-fold longer survival $(p=0.008)$ [74]. The association between pre-diagnostic lipid levels and ALS risk was studied in a large nested case-control study involving 275 individuals from five prospective US cohorts (the Nurses' Health Study, the Health Professionals Follow-up Study, the Cancer Prevention Study II Nutrition Cohort, the Multiethnic Cohort Study, and the Women's Health Initiative): after a follow-up period, higher ALS risk was associated with higher HDL, while null results were reported for the other plasma lipids (including TC, LDL-C, and TG) [75].

Concerning survival, patients with ALS who had high LDL/HDL ratios lived longer than those with a low LDL/HDL ratio [48]. Several other studies reported that ALS patients with dyslipidemia or higher cholesterol levels were more likely to have a longer survival rate than those with no lipid abnormalities [48,50,56-59,76,77]. However, others found no association between plasma lipid levels and ALS survival [51,54,78], although a decrease in LDL/HDL ratio has been reported to be associated with a high rate of respiratory impairment [49].

A possible common pathologic pathway linking dyslipidemia to ALS could involve the mitochondrial system, which could explain the impaired energy balance seen in ALS. In ALS, there is accumulating evidence that mitochondrial dysfunction may play a significant role in the disease mechanisms [79-81]. In an older study, intracellular analysis 
of the hepatocytes studied in 21 liver biopsies, obtained from ALS patients, revealed a number of alterations, including an abnormal mitochondria with paracrystalline inclusions, abnormal lamellar structure of rough endoplasmic reticulum, higher number of smooth endoplasmic reticulum, and para-sinusoidal fibrosis [82]. Moreover, postmortem histologic examinations have also shown a more pronounced steatosis of liver in ALS patients (despite weight loss) than in other neurological diseases [48]. Mitochondrial dysfunction has been associated with insulin resistance in skeletal muscle and insulin-resistant individuals show characteristic changes from the normal lipid and lipoprotein pattern [83]. These changes include the elevation of triglycerides, reduction in HDL, and a concomitant increase in LDL [75]. The presence of dyslipidemia in ALS could reflect an intrinsic abnormality or a physiological attempt to compensate for an abnormal metabolic state [84]. The understanding of such evidence and the mechanisms underlying these abnormalities are not clear, but it may be important to monitor blood lipids to assess the risk of survival [72].

\section{BMI Changes in ALS}

BMI is a surrogate measure to identify an excess in weight, adjusted for height, and calculated as weight in kilograms divided by the square of height in meters $\left(\mathrm{kg} / \mathrm{m}^{2}\right)$ [85]. A recent pooled analysis conducted on about 400 thousand women (428 ALS deaths) and nearly 150 thousand men (204 ALS deaths) from 10 community-based cohorts in the USA, Europe and Australia, aiming to explore the relationships between ALS death and preclinical anthropometric measures, showed that weight-gain during adulthood was a strong predictor for lower mortality risk from ALS [86]. In a case-control study conducted on 279 individuals, subjects with motor neuron diseases $(n=279)$ were more likely to report they had always been slim compared to controls [87]. A retrospective study assessing BMI and cholesterol levels in 427 ALS patients found that a decrease in BMI was associated with lower survival, irrespective of other comorbidities (including cardiovascular disease) associated with a high BMI [52].

A more recent prospective cohort study (enrolling 537,968 females and 562,942 males) recorded weight at time of enrollment, recalled weight at age 18/21 years, and were followed over 14-28 years; among the 1153 participants who developed ALS during the follow-up period, ALS rates were significantly lower among the overweight (odds ratio (OR) 0.76 ; $95 \%$ CI, 0.62 to 0.93 ) and obese (OR $0.73 ; 95 \%$ CI, 0.55 to 0.96 ) individuals compared to those with normal BMI, while being underweight was associated with higher risk of ALS (risk of ALS for a 5-unit increase in BMI was 0.79 (95\% CI: 0.73 to 0.86, $p<0.0001)$ ) [88].

In another prospective study [89], 222 ALS deaths occurred in the European Prospective Investigation into Cancer and Nutrition cohort study (involving 518,108 individuals) after a 13-year follow-up period, registering a higher mortality risk from ALS in underweight individuals ( $\mathrm{HR}=2.79,95 \% \mathrm{CI} 1.35$ to 5.77 ), while no association was found for the analyses of waist and hip circumferences and waist/hip ratio with ALS mortality [89].

A BMI decrease in ALS may depend on both a loss in FM, but also in muscle atrophy [90]. Among the factors that could contribute to changes in BMI, there are changes in sensory stimuli (olfaction and gustation), potentially leading to loss of appetite at earlier stages, as well as impairment of autonomy following the progression of the disease or side effects of medication [91]. In general, a lower BMI before the onset of the disease cannot be considered a specific risk factor for ALS, although it seems that weight loss needs to be monitored and counteracted after ALS diagnosis, as it has consistently been associated with a worse prognosis [52,92,93].

\section{Hypermetabolism in ALS \\ Energy Expenditure}

Energy homoeostasis represents the balance between energy intake from food and nutrients and energy expenditure, including resting energy expenditure (REE) and total daily energy expenditure (TDEE) [94]. An estimation of TDEE has not been standardized 
for ALS patients, although equations can now be used to estimate the energy requirements of ALS patients [95]. In a prospective multicenter study, REE was evaluated by indirect calorimetry in 80 ALS patients, and physical activity and body composition (lean and fat mass) were found to influence REE [95]. TDEE were estimated by Harris-Benedict, Mifflin-St Jeor, and Owen equations. Among these estimates, the Harris-Benedict equation was found to be the most practical formula for use in the care of ALS patients. The Harris-Benedict equation can estimate an individual's daily calorie requirements, based on weight, height, age and sex, and taking activity level into account, to determine the TDEE [96]. However, this equation is most predictive when considering a normal body composition; therefore, it may not be accurate in ALS patients, who tend to be lean, with a normal or low BMI $[97,98]$, and typically suffer from weight loss as the disease develops [99]. Thus, it is important to integrate the predictive validity of the equations to determine the energy needs with other methods, which may help to confirm the estimated requirements [100,101]. TDEE may be best estimated by using specific methods, such as indirect calorimetry and/or a double-labelled water system to assess REE and by taking correction factors into account (dietary-induced thermogenesis and physical activity) [102]. A comparison between the recorded values of REE with a theoretically calculated energy expenditure leads to a metabolism ratio, indicating hypermetabolism if ratio $>1$. Increased energy expenditure was reported in sporadic $(n=62)$ ALS $[103,104]$, and 11 patients with familial ALS (fALS) [105]. In a study enrolling 26 Japanese ALS patients measuring the TDEE using the double-labelled water method for a 14-day period, a new logarithmic equation using the REE estimated by the Harris-Benedict equation and scores by the ALSFRS-R has been developed for ALS patients [106].

Hypermetabolism was found in ALS (up to $60 \%$ of patients), even with denervation and a rapid reduction in physical activity, which cause disuse muscle atrophy in ALS patients [103]. Thus, compensation for REE increase through diet is needed to avoid weight loss [107]. REE is positively correlated with muscle mass and inversely correlated with age, and is greater in men than in women [103]. TDEE seems to be significantly decreased with the progression of ALS stage and does not vary by sex [108]. A recent study, enrolling 315 ALS patients, showed that the trajectory of ALSFRS-R was not significatively influenced by a high or low REE [107]. In one study assessing REE in 58 ALS patients and 58 age- and sex-matched controls, ALS patients were more likely to have hypermetabolism than controls (OR $=5.4,95 \%$ CI: 2.1 to 13.8, $p<0.01)$ [109]. During the 12 months of follow-up, there was a greater change in ALSFRS-R, which was inversely associated with hypermetabolic state (HR = 3.2, 95\% CI: 1.1 to 9.4, $p=0.03$ ) [109]. The hypermetabolism phenomenon was also studied in 62 patients and 31 healthy controls in a case-control study, in which REE in ALS patients was significantly higher than that of the control group $(p=0.03)$ [103]. The only laboratory variable that correlated with REE was the neutrophil count, although the reasons for this were unknown [103]. In another study, consecutive evaluations of REE from diagnosis to death in 44 ALS patients, REE levels remained higher than calculated values of an increase of $14 \%$, followed by a trend for REE to decrease near death, whereas fat-free mass remained stable. Hypermetabolism was found in $62.3 \%$ of ALS patients. In multivariate analysis, REE was negatively linked to age and positively linked with fat-free mass [104]. A prospective 2-year longitudinal nutritional assessment in 61 ALS patients showed that about half of the patients were hypermetabolic, and hypermetabolism persisted even after adjustment for energy homeostasis over the follow-up period [110].

Hypermetabolism may lead to an anomalous lipid usage with a discrepancy between peripheric lipid stores' mobilization and metabolic/nutritional status [103], although the underlying mechanisms are poorly understood. The possible reasons for such a conduction may include (i) the impact of the neurodegeneration of sympathetic nerve innervation of adipose tissue, which could affect the mobilization capacity of energy stores [64,111], which has been demonstrated, to some extent, to affect ALS patients [112]; (ii) higher energy expenditure for basic activities (i.e., breathing) due to muscle atrophy, fasciculations and spasticity [113]; (iii) mitochondria abnormalities with decreased energy pro- 
duction [114]; (iv) establishment of a pro-inflammatory state with increased production of pro-inflammatory cytokines by leukocytes $[115,116]$; (v) production of reactive oxygen species and increase in oxidative stress damage [117]. Among the aforementioned factors, mitochondrial metabolism was found to be hypermetabolic in ALS, involving both oxidative phosphorylation and glycolysis. This is not accompanied by an increase in mitochondrial ATP production, perhaps due to a compensatory adaptation to higher ATP demands [118]. It is intriguing to know that these cultured cells appear to show intrinsic mitochondrial or metabolic abnormalities in ALS. Although likely to involved in the hypermetabolism state, mitochondrial dysfunction in ALS is not ubiquitous in body cells [119]. Thus, we cannot exclude the possibility that it represents an epiphenomenon not causally related to ALS prognosis.

\section{Malnutrition in ALS}

Malnutrition is defined as weight loss exceeding $10 \%$ of the basal/previous weight or BMI < 18.5 [120]. Cachexia is a complex metabolic condition associated with an underlying disease, characterized by weight loss due to loss of muscle (with or without loss of FM), accompanied by a general inflammatory state [121]. Malnutrition can commonly be observed in ALS patients, with a prevalence rate of up to about $50 \%[113,122]$. Using a $\mathrm{BMI} \leq 18.5$ as a cut-off, malnutrition was found in up to $20 \%$ of ALS patients, associated with a faster progression of motor symptoms, decreased survival time, and higher mortality risk $[123,124]$. In a French population-based study enrolling 322 ALS patients, those who had a weight loss of $10 \%$ or more at the time of diagnosis experienced a $45 \%$ increase in mortality risk compared to patients, experiencing a weight loss of lower than $5 \%$ or no weight loss [125].

A more recent prospective study from The Netherlands ALS Centre national database, investigating the prevalence and prognostic value of weight at the time of ALS diagnosis in 2420 patients, $67.5 \%$ of whom reported weight loss at first referral, showed that weight loss was a predictor of survival, with a $23 \%$ increased risk of death for every $10 \%$ increase in weight loss relative to body weight (HR 1.23, 95\% CI: 1.13 to 1.51, $p<0.001$ ) [93]. Similar results were shown in 63 ALS patients, for which the mean disease duration was significantly shorter in the subgroup of patients with weight loss exceeding $10 \%$ than in other patients [126]. On the other hand, stable weight at diagnosis was shown to be important, because patients who lost less than $5 \%$ of their usual body weight in the six months prior to ALS diagnosis had a higher median survival than those with higher body weight loss [61]. Out of the 40 ALS patients who were enrolled in a home network of surveillance, three patients were clinically malnourished and reported having unbalanced diets, with insufficient protein, high fat intake and not enough carbohydrate compared with French dietary recommendations [127]. In general, patients with ALS tend to assume an inadequate caloric intake, with about $15-16 \%$ fewer calories than recommended [99]. Poor dietary intake could be caused by dysphagia, taste disorders, or poor assistance being required during the meals [128]. Therefore, appropriate nutritional assessment and proper nutritional care is an important management aspect for patients with ALS [129].

\section{Nutritional Epidemiology Studies of ALS}

Table 2 shows epidemiological studies of macronutrients, micronutrients, and other food items in relation to the occurrence of ALS. Some studies showed that higher consumption of polyunsaturated fatty acids (PUFA) may play a protective role against ALS. A pooled analysis of five US cohorts (the Health Professionals' Follow-up Study (HPFS), the Nurses' Health Study (NHS), the Cancer Prevention II-Nutrition Cohort (CPS-II Nutrition), the Multiethnic Cohort Study (MEC) and the National Institutes of Health-AARP Diet and Health Study (NIH-AARP)) including more than 1 million individuals and a total of 995 ALS cases showed that a higher n-3 PUFA intake was associated with a $34 \%$ lower risk for ALS compared to the lowest intake (RR 0.66; 95\% CI: 0.53 to 0.81 ; $p$ for trend <0.001), with no evidence of association for n-6 PUFA [130]. Notably, both plant-derived alpha- 
linolenic acid (the main n-3 PUFA from vegetable sources) and marine n-3 PUFA were associated with lower ALS risk. The mechanisms underlying these findings include the ability of PUFA to modulate the cellular inflammatory response and act against oxidative stress [131]. Evidence of glutamate intake and risk of ALS is rather contrasting, with a study reporting higher risk [132] and another reporting null findings [133]. A population-based, case-control study in Netherlands showed that individuals with a higher preclinical intake of total fat (OR 1.14; 95\% CI: 1.07 to 1.23; $p<0.001)$, saturated fat (OR 1.43; 95\% CI:1.25 to $1.64 ; p<0.001$ ), trans-fatty acids (OR 1.03; 95\% CI: 1.01 to $1.05 ; p<0.001$ ), and cholesterol (OR 1.08; 95\% CI: 1.05 to 1.12; $p<0.001$ ) were more likely to have ALS while a higher intake of alcohol was inversely associated with the likelihood of having ALS (OR 0.91; 95\% CI: 0.84 to $0.99 ; p=0.03$ ) [134]. Another study conducted in three Italian regions involving 212 cases and matched controls showed an inverse association between coffee and tea $(\mathrm{OR}=0.29,95 \% \mathrm{CI} 0.14$ to 0.60 ), whole bread ( $\mathrm{OR}=0.55,95 \% \mathrm{CI} 0.31$ to 0.99 ), raw vegetables ( $\mathrm{OR}=0.25,95 \% \mathrm{CI} 0.13$ to 0.52$)$ and citrus fruits (OR $=0.49,95 \% \mathrm{CI} 0.25$ to 0.97) and likelihood of having ALS, and a direct association with red and processed meat $(\mathrm{OR}=2.96,95 \% \mathrm{CI} 1.46$ to 5.99 and $\mathrm{OR}=3.87,95 \% \mathrm{CI} 1.86$ to 8.07 , respectively), increased total and animal protein intake (OR $=2.96,95 \% \mathrm{CI} 1.08$ to 8.10 and $\mathrm{OR}=2.91,95 \% \mathrm{CI}$ 1.33 to 6.38 , respectively), sodium ( $\mathrm{OR}=3.96,95 \% \mathrm{CI} 1.45$ to 10.84$)$, zinc $(\mathrm{OR}=2.78$, $95 \%$ CI 1.01 to 7.83$)$ and glutamic acid (OR $=3.63,95 \%$ CI 1.08 to 12.2) [135]. Another case-control study found a negative association with high carbohydrate intake [136], but this was not confirmed in two population-based studies [132,133]. There are inconclusive results regarding the relationship between vitamin E consumption and risk of ALS: an inverse association was reported in a case-control [137] and a cohort study [138] but null results were found in two other case-control studies $[139,140]$. A recent pooled analysis showed lower ALS rates among individuals with the highest dietary vitamin E intake, but in multivariable adjustment, this finding was no longer significant [141]. However, increasing years of supplementation with vitamin $\mathrm{E}$ was inversely related with the likelihood of having ALS [141]. 
Table 2. Summary of studies on food intake in ALS.

\begin{tabular}{|c|c|c|c|c|}
\hline Authors, and Date of Publication & Study Design, Country & Number of ALS/Controls & Macro and Micronutrients Investigated & Main Findings \\
\hline Nelson, 2000 [132] & Case-control, US & $161 / 321$ & $\begin{array}{c}\text { carbohydrates, proteins, fats, vitamins and } \\
\text { minerals }\end{array}$ & $\begin{array}{l}\text { High intake of glutamate }(>15.07 \mathrm{~g} / \text { day }) \\
\text { saturated fats }(p<0.001), \text { and PUFA } \\
(p<0.001) \text { were associated with ALS. }\end{array}$ \\
\hline Longnecker, 2000 [139] & Case-control, US & $107 / 262$ & calcium, magnesium, vitamins & No positive or negative association with ALS. \\
\hline Ascherio, 2005 [138] & $\begin{array}{l}\text { Mortality surveillance in a } \\
\text { Cancer cohort, US }\end{array}$ & $525 / 957,740$ & vitamins $\mathrm{E}$ and $\mathrm{C}$ & $\begin{array}{l}\text { Age- and smoking-adjusted relative risk to } \\
\text { develop ALS in regular users of vitamin E for } \\
10 \text { or more years was higher than non-users } \\
\qquad(p<0.001) \text {. }\end{array}$ \\
\hline Okamoto, 2007 [136] & Case-control, Japan & $153 / 306$ & $\begin{array}{l}\text { carbohydrates, saturated and } \\
\text { unsaturated fat }\end{array}$ & $\begin{array}{c}\text { Carbohydrate intake }(>295 \text { g per day) was } \\
\text { directly associated with ALS }(p<0.001) \\
\text { PUFA }(p<0.001) \text {, saturated fatty acids } \\
(p<0.001) \text { and monounsaturated fatty acids } \\
(p<0.001) \text { were inversely associated } \\
\text { with ALS. }\end{array}$ \\
\hline Veldink, 2007 [137] & Case-control, Netherlands & $132 / 220$ & $\begin{array}{l}\text { PUFAs, glutamate, flavonol, lycopene, } \\
\text { vitamin C, vitamin B2, vitamin E calcium } \\
\text { or phytoestrogens }\end{array}$ & $\begin{array}{l}\text { PUFAs and vitamin E intake were inversely } \\
\text { associated with ALS ( } p<0.001 \text { and } \\
p<0.001 \text {, respectively). }\end{array}$ \\
\hline Morozova, 2008 [133] & $\begin{array}{l}\text { Mortality surveillance Cancer } \\
\text { cohort, US }\end{array}$ & $841 /$ over 1 million & $\begin{array}{c}\text { carbohydrates, proteins, fats, vitamins } \\
\text { and minerals }\end{array}$ & $\begin{array}{l}\text { Consumption of chicken was inversely } \\
\text { related to risk of ALS }(p<0.001) .\end{array}$ \\
\hline Okamoto, 2009 [140] & Case-control, Japan & $153 / 306$ & fruits and vegetables & $\begin{array}{l}\text { Not significant lower odds of ALS with } \\
\text { intake of fruit and vegetables. }\end{array}$ \\
\hline Wang, 2011 [141] & $\begin{array}{l}\text { Pooled analysis of data from } 5 \\
\text { prospective cohorts, US }\end{array}$ & $805 / 1,055,546$ & vitamin $\mathrm{E}$ & $\begin{array}{l}\text { ALS rates declined with longer years of use } \\
\text { of vitamin } E \text { ( } p \text { for trend }=0.01) .\end{array}$ \\
\hline Fitzgerald, 2013 [142] & $\begin{array}{l}\text { Pooled analysis of data from } 5 \\
\text { prospective cohorts, US }\end{array}$ & $1153 / 1,100,910$ & vitamin $\mathrm{C}$ and carotenoids & $\begin{array}{l}\text { Total carotenoids and lutein intake was } \\
\text { associated with decreased risk of ALS ( } p \text { for } \\
\text { trend }=0.004 \text { and } p \text { for trend }=0.01 \text {, } \\
\text { respectively). Lycopene, } \beta \text {-cryptoxanthin, } \\
\text { and vitamin C were not associated with } \\
\text { decreased risk of ALS. }\end{array}$ \\
\hline
\end{tabular}


Table 2. Cont.

\begin{tabular}{|c|c|c|c|c|}
\hline Authors, and Date of Publication & Study Design, Country & Number of ALS/Controls & Macro and Micronutrients Investigated & Main Findings \\
\hline Fitzgerald, 2014 [130] & $\begin{array}{c}\text { Pooled analysis of data from } 5 \\
\text { prospective cohorts, US }\end{array}$ & $995 / 1,002,082$ & dietary fat intakes & $\begin{array}{l}\text { N-3 PUFA intake was associated with a lower } \\
\text { risk for ALS ( } p \text { for trend }<0.001 \text { ). The } \\
\text { observed reduced risk was found for both } \\
\text { ALA ( } p \text { for trend }=0.003 \text { ) and marine } n-3 \\
\text { PUFA intake ( } p \text { for trend }=0.03 \text { ). }\end{array}$ \\
\hline Fondell, 2013 [143] & $\begin{array}{l}\text { Pooled analysis of data from } 5 \\
\text { prospective cohorts, U.S. }\end{array}$ & $1093 / 1,050,000$ & dietary magnesium intake & $\begin{array}{l}\text { Dietary intake of magnesium was not } \\
\text { associated with ALS risk. }\end{array}$ \\
\hline Park, 2015 [106] & Case study, Korea & $193 /-$ & $\begin{array}{c}\text { carbohydrates, proteins, fats, vitamins } \\
\text { and minerals }\end{array}$ & $\begin{array}{l}\text { Patients in the lowest values of ALSFRS-R } \\
\text { consumed fewer vegetables, grains, } \\
\text { seasonings, oils, and meats than others, but } \\
\text { higher amounts of fruits and beans. }\end{array}$ \\
\hline Nieves, 2016 [144] & $\begin{array}{l}\text { Cross-sectional baseline } \\
\text { analysis on ALS cohort, US }\end{array}$ & $302 /-$ & $\begin{array}{c}\text { carbohydrates, proteins, fats, vitamins } \\
\text { and minerals }\end{array}$ & $\begin{array}{l}\text { Increased consumption of antioxidants and } \\
\text { carotenoids was associated with higher } \\
\text { ALSFRS-R scores or percentage FVC. }\end{array}$ \\
\hline Pupillo, 2018 [135] & Case-control, Italy & $212 / 212$ & $\begin{array}{c}\text { carbohydrates, proteins, fats, vitamins } \\
\text { and minerals }\end{array}$ & $\begin{array}{l}\text { Higher intake of coffee, tea, whole bread, raw } \\
\text { vegetables, and citrus fruits was associated } \\
\text { with significantly higher ALSFRS-R scores or } \\
\text { percentage FVC. Higher risk was associated } \\
\text { with higher consumption of red and } \\
\text { processed meat, total and animal protein, } \\
\text { sodium, zinc, and glutamic acid. }\end{array}$ \\
\hline Kim, 2020 [145] & Retrospective & $148 /-$ & carbohydrates, proteins, fats & $\begin{array}{l}\text { Fat, protein, and meat intake was positively } \\
\text { associated with survival time of ALS patients. }\end{array}$ \\
\hline
\end{tabular}


The intake of carotenoids and ALS risk has been investigated in case-control studies $[139,140]$ reporting a lower risk of ALS among individuals with higher lycopene intake [139] and inverse ALS rates across quartiles of beta-carotene [140]. Further evidence has been ported in a pooled analysis of five prospective cohorts, accounting for a total of 1153 ALS deaths among more than 1,000,000 participants, showing an inverse relationship between total intake of carotenoids, beta carotene and lutein and ALS risk [142]. Other investigated micronutrients, such as calcium, magnesium and vitamin $C$, have shown no association with risk of ALS [139,142,143]. A recent cross-sectional study, including 302 newly diagnosed ALS patients, reported that antioxidants, carotenes, and their major food sources, fruits and vegetables, were associated with higher ALS function; specifically, lutein, zeaxanthin, and n-3 PUFA intake was associated with ALSFRS-R score, and n-3 and n-6 PUFA intake was associated with FVC percentage [144]. Regarding animal-derived foods, a study reported that survival time was associated with fat, protein, and meat intake [145].

The putative protective action observed for n-3 PUFA, carotenoids, and Vitamin E could be due to the antioxidant activity of these micronutrients [146], as oxidative stress is a well-described phenomenon in ALS $[147,148]$. These epidemiological studies suggest that antioxidative micronutrients are associated with lower risk of ALS and better motor function in patients with ALS. It may be worth accounting for the individual genetic risk factors which modulate the metabolism of any macro- or micronutrient; for instance, a genetic variation in the beta-carotene monooxygenase gene could influence the bioavailability of this micronutrient [149].

\section{Conclusions}

Metabolic and nutritional factors seem to play a role in some of the mechanisms involved in ALS development. Notably, energy metabolism appears impaired and energy expenditure is increased to a hypermetabolic state in a higher proportion of ALS patients. However, the causes of these abnormalities are still unclear, and only a few studies have investigated the energy metabolism of patients before the development of ALS. Metabolic changes in patients with ALS occur from the onset and throughout disease progression, and whether the changes precede the diagnosis is unknown. Overall, the observed hypermetabolic state and weight loss may lead to muscle loss and cachexia. Thus, weight maintenance in normal weighted patients or weight gain in underweighted ALS patients should lead to better prognosis. Importantly, an estimation of the energy requirements should take the hypermetabolic state and possible increased needs into account. There is not enough evidence to support any specific dietary intervention regarding macronutrient or food content, or antioxidant supplement formulation over another. However, since ALS may lead to cachexia at the end stages, the preparation of nutritionally adequate meal plans with the inclusion of antioxidant and anti-inflammatory (and limited pro-inflammatory) dietary factors may be advisable. Thus, nutritional evaluation of ALS patients should be included at the first referral of the ALS patient and continued during the follow-up visits in order to ensure adequate energy and nutrient intake over the time of disease progression. Further studies are needed to better investigate the metabolic and nutritional aspects related to the mechanisms of ALS and to provide better nutritional care in patients with ALS. Future studies, including genetic, biochemical, and nutritional investigations, are of paramount importance to clarify the role of nutrition in ALS.

Author Contributions: Conceptualization, E.D., G.G., A.Z.; methodology, J.W.N., P.F.-L., H.M., E.D., G.G.; writing—original draft preparation, E.D., G.G., A.Z.; writing-review and editing, E.D., G.G., A.Z.; funding acquisition, H.M. All authors have read and agreed to the published version of the manuscript.

Funding: This research was funded by NINDS (R01ES016348), CDC (200-2013-56886 and R01TS000243) and MDA Wings Over Wall Street (for H.M.).

Institutional Review Board Statement: Not applicable. 
Informed Consent Statement: Not applicable.

Conflicts of Interest: The authors declare no conflict of interest.

\section{References}

1. Rio, A.; Ellis, C.; Shaw, C.; Willey, E.; Ampong, M.A.; Wijesekera, L.; Rittman, T.; Nigel Leigh, P.; Sidhu, P.S.; Al-Chalabi, A. Nutritional Factors Associated with Survival Following Enteral Tube Feeding in Patients with Motor Neurone Disease. J. Hum. Nutr. Diet. 2010, 23, 408-415. [CrossRef]

2. Chiò, A.; Logroscino, G.; Traynor, B.J.; Collins, J.; Simeone, J.C.; Goldstein, L.A.; White, L.A. Global Epidemiology of Amyotrophic Lateral Sclerosis: A Systematic Review of the Published Literature. Neuroepidemiology 2013, 41, 118-130. [CrossRef]

3. Beghi, E.; Chiò, A.; Couratier, P.; Esteban, J.; Hardiman, O.; Logroscino, G.; Millul, A.; Mitchell, D.; Preux, P.-M.; Pupillo, E.; et al. The Epidemiology and Treatment of ALS: Focus on the Heterogeneity of the Disease and Critical Appraisal of Therapeutic Trials. Amyotroph. Lateral Scler. 2011, 12, 1-10. [CrossRef] [PubMed]

4. Andersen, P.M.; Al-Chalabi, A. Clinical Genetics of Amyotrophic Lateral Sclerosis: What Do We Really Know? Nat. Rev. Neurol. 2011, 7, 603-615. [CrossRef]

5. Kiernan, M.C.; Vucic, S.; Cheah, B.C.; Turner, M.R.; Eisen, A.; Hardiman, O.; Burrell, J.R.; Zoing, M.C. Amyotrophic Lateral Sclerosis. Lancet 2011, 377, 942-955. [CrossRef]

6. Wicklund, M.P. Amyotrophic Lateral Sclerosis: Possible Role of Environmental Influences. Neurol. Clin. 2005, 23, 461-484. [CrossRef] [PubMed]

7. Salvucci, E. The Human-Microbiome Superorganism and Its Modulation to Restore Health. Int. J. Food Sci. Nutr. 2019, 70, 781-795. [CrossRef] [PubMed]

8. Di Gioia, D.; Bozzi Cionci, N.; Baffoni, L.; Amoruso, A.; Pane, M.; Mogna, L.; Gaggìa, F.; Lucenti, M.A.; Bersano, E.; Cantello, R.; et al. A Prospective Longitudinal Study on the Microbiota Composition in Amyotrophic Lateral Sclerosis. BMC Med. 2020, 18, 153. [CrossRef] [PubMed]

9. Hardiman, O.; Al-Chalabi, A.; Chio, A.; Corr, E.M.; Logroscino, G.; Robberecht, W.; Shaw, P.J.; Simmons, Z.; van den Berg, L.H. Amyotrophic Lateral Sclerosis. Nat. Rev. Dis. Primers 2017, 3, 17071. [CrossRef] [PubMed]

10. Turner, M.R. Progress and New Frontiers in Biomarkers for Amyotrophic Lateral Sclerosis. Biomark. Med. 2018, 12, 693-696. [CrossRef] [PubMed]

11. Grad, L.I.; Rouleau, G.A.; Ravits, J.; Cashman, N.R. Clinical Spectrum of Amyotrophic Lateral Sclerosis (ALS). Cold Spring Harb. Perspect. Med. 2017, 7. [CrossRef]

12. Miller, R.G.; Jackson, C.E.; Kasarskis, E.J.; England, J.D.; Forshew, D.; Johnston, W.; Kalra, S.; Katz, J.S.; Mitsumoto, H.; Rosenfeld, J.; et al. Practice Parameter Update: The Care of the Patient with Amyotrophic Lateral Sclerosis: Multidisciplinary Care, Symptom Management, and Cognitive/Behavioral Impairment (an Evidence-Based Review): Report of the Quality Standards Subcommittee of the American Academy of Neurology. Neurology 2009, 73, 1227-1233. [CrossRef]

13. Writing Group; Edaravone (MCI-186) ALS 19 Study Group Safety and Efficacy of Edaravone in Well Defined Patients with Amyotrophic Lateral Sclerosis: A Randomised, Double-Blind, Placebo-Controlled Trial. Lancet Neurol. 2017, 16, 505-512. [CrossRef]

14. Turnbull, J. Is Edaravone Harmful? (A Placebo Is Not a Control). Amyotroph. Lateral Scler. Front. Degener. 2018, 19, 477-482. [CrossRef] [PubMed]

15. Turnbull, J. Reappraisal of an ALS Trial: Unaccounted Procedural Risk. Lancet Neurol. 2020, 19, 717-718. [CrossRef]

16. Miller, R.G.; Anderson, F.; Brooks, B.R.; Mitsumoto, H.; Bradley, W.G.; Ringel, S.P.; ALS CARE Study Group. Outcomes Research in Amyotrophic Lateral Sclerosis: Lessons Learned from the Amyotrophic Lateral Sclerosis Clinical Assessment, Research, and Education Database. Ann. Neurol. 2009, 65 (Suppl. S1), S24-S28. [CrossRef] [PubMed]

17. Miller, R.G.; Brooks, B.R.; Swain-Eng, R.J.; Basner, R.C.; Carter, G.T.; Casey, P.; Cohen, A.B.; Dubinsky, R.; Forshew, D.; Jackson, C.E.; et al. Quality Improvement in Neurology: Amyotrophic Lateral Sclerosis Quality Measures: Report of the Quality Measurement and Reporting Subcommittee of the American Academy of Neurology. Neurology 2013, 81, 2136-2140. [CrossRef] [PubMed]

18. Miller, R.G.; Rosenberg, J.A.; Gelinas, D.F.; Mitsumoto, H.; Newman, D.; Sufit, R.; Borasio, G.D.; Bradley, W.G.; Bromberg, M.B.; Brooks, B.R.; et al. Practice Parameter: The Care of the Patient with Amyotrophic Lateral Sclerosis (an Evidence-Based Review): Report of the Quality Standards Subcommittee of the American Academy of Neurology: ALS Practice Parameters Task Force. Neurology 1999, 52, 1311-1323. [CrossRef]

19. Blasco, H.; Veyrat-Durebex, C.; Bocca, C.; Patin, F.; Vourc'h, P.; Kouassi Nzoughet, J.; Lenaers, G.; Andres, C.R.; Simard, G.; Corcia, P.; et al. Lipidomics Reveals Cerebrospinal-Fluid Signatures of ALS. Sci. Rep. 2017, 7, 17652. [CrossRef]

20. Abdel-Khalik, J.; Yutuc, E.; Crick, P.J.; Gustafsson, J.-Å.; Warner, M.; Roman, G.; Talbot, K.; Gray, E.; Griffiths, W.J.; Turner, M.R.; et al. Defective Cholesterol Metabolism in Amyotrophic Lateral Sclerosis. J. Lipid Res. 2017, 58, 267-278. [CrossRef] [PubMed]

21. Tefera, T.W.; Borges, K. Metabolic Dysfunctions in Amyotrophic Lateral Sclerosis Pathogenesis and Potential Metabolic Treatments. Front. Neurosci. 2016, 10, 611. [CrossRef]

22. Nakayama, Y.; Shimizu, T.; Matsuda, C.; Haraguchi, M.; Hayashi, K.; Bokuda, K.; Nagao, M.; Kawata, A.; Ishikawa-Takata, K.; Isozaki, E. Body Weight Variation Predicts Disease Progression after Invasive Ventilation in Amyotrophic Lateral Sclerosis. Sci. Rep. 2019, 9, 12262. [CrossRef] 
23. Godos, J.; Currenti, W.; Angelino, D.; Mena, P.; Castellano, S.; Caraci, F.; Galvano, F.; Del Rio, D.; Ferri, R.; Grosso, G. Diet and mental health: Review of the recent updates on molecular mechanisms. Antioxidants 2020, 9, 346. [CrossRef]

24. Kellogg, J.; Bottman, L.; Arra, E.J.; Selkirk, S.M.; Kozlowski, F. Nutrition Management Methods Effective in Increasing Weight, Survival Time and Functional Status in ALS Patients: A Systematic Review. Amyotroph. Lateral Scler. Front. Degener. 2018, 19 , 7-11. [CrossRef]

25. Dupuis, L.; Pradat, P.-F.; Ludolph, A.C.; Loeffler, J.-P. Energy Metabolism in Amyotrophic Lateral Sclerosis. Lancet Neurol. 2011, 10, 75-82. [CrossRef]

26. Mitchell, C.S.; Hollinger, S.K.; Goswami, S.D.; Polak, M.A.; Lee, R.H.; Glass, J.D. Antecedent Disease Is Less Prevalent in Amyotrophic Lateral Sclerosis. Neurodegener. Dis. 2015, 15, 109-113. [CrossRef]

27. Reyes, E.T.; Perurena, O.H.; Festoff, B.W.; Jorgensen, R.; Moore, W.V. Insulin Resistance in Amyotrophic Lateral Sclerosis. J. Neurol. Sci. 1984, 63, 317-324. [CrossRef]

28. Perurena, O.H.; Festoff, B.W. Reduction in Insulin Receptors in Amyotrophic Lateral Sclerosis Correlates with Reduced Insulin Sensitivity. Neurology 1987, 37, 1375-1379. [CrossRef] [PubMed]

29. Harno, K.; Rissanen, A.; Palo, J. Glucose Tolerance in Amyotrophic Lateral Sclerosis. Acta Neurol. Scand. 1984, 70, 451-455. [CrossRef] [PubMed]

30. Jawaid, A.; Brown, J.A.; Schulz, P.E. Diabetes Mellitus in Amyotrophic Lateral Sclerosis: Dr. Jekyll or Mr. Hyde? Eur. J. Neurol. 2015, 22, 1419-1420. [CrossRef]

31. Cowie, C.C.; Rust, K.F.; Byrd-Holt, D.D.; Eberhardt, M.S.; Flegal, K.M.; Engelgau, M.M.; Saydah, S.H.; Williams, D.E.; Geiss, L.S.; Gregg, E.W. Prevalence of Diabetes and Impaired Fasting Glucose in Adults in the U.S. Population: National Health And Nutrition Examination Survey 1999-2002. Diabetes Care 2006, 29, 1263-1268. [CrossRef]

32. Mariosa, D.; Hammar, N.; Malmström, H.; Ingre, C.; Jungner, I.; Ye, W.; Fang, F.; Walldius, G. Blood Biomarkers of Carbohydrate, Lipid, and Apolipoprotein Metabolisms and Risk of Amyotrophic Lateral Sclerosis: A More than 20-Year Follow-up of the Swedish AMORIS Cohort. Ann. Neurol. 2017, 81, 718-728. [CrossRef]

33. Jawaid, A.; Salamone, A.R.; Strutt, A.M.; Murthy, S.B.; Wheaton, M.; McDowell, E.J.; Simpson, E.; Appel, S.H.; York, M.K.; Schulz, P.E. ALS Disease Onset May Occur Later in Patients with Pre-Morbid Diabetes Mellitus. Eur. J. Neurol. 2010, 17, 733-739. [CrossRef] [PubMed]

34. D'Ovidio, F.; d'Errico, A.; Carnà, P.; Calvo, A.; Costa, G.; Chiò, A. The Role of Pre-Morbid Diabetes on Developing Amyotrophic Lateral Sclerosis. Eur. J. Neurol. 2018, 25, 164-170. [CrossRef] [PubMed]

35. Schumacher, J.; Peter, R.S.; Nagel, G.; Rothenbacher, D.; Rosenbohm, A.; Ludolph, A.C.; Dorst, J.; ALS Registry Swabia Study Group Statins. Diabetes Mellitus and Prognosis of Amyotrophic Lateral Sclerosis: Data from 501 Patients of a Population-Based Registry in Southwest Germany. Eur. J. Neurol. 2020, 27, 1405-1414. [CrossRef] [PubMed]

36. Paganoni, S.; Hyman, T.; Shui, A.; Allred, P.; Harms, M.; Liu, J.; Maragakis, N.; Schoenfeld, D.; Yu, H.; Atassi, N.; et al. Pre-Morbid Type 2 Diabetes Mellitus Is Not a Prognostic Factor in Amyotrophic Lateral Sclerosis. Muscle Nerve 2015, 52, 339-343. [CrossRef]

37. Sun, Y.; Lu, C.-J.; Chen, R.-C.; Hou, W.-H.; Li, C.-Y. Risk of Amyotrophic Lateral Sclerosis in Patients with Diabetes: A Nationwide Population-Based Cohort Study. J. Epidemiol. 2015, 25, 445-451. [CrossRef]

38. Wei, Q.-Q.; Chen, Y.; Cao, B.; Ou, R.W.; Zhang, L.; Hou, Y.; Gao, X.; Shang, H. Blood Hemoglobin A1c Levels and Amyotrophic Lateral Sclerosis Survival. Mol. Neurodegener. 2017, 12, 69. [CrossRef]

39. Mariosa, D.; Kamel, F.; Bellocco, R.; Ye, W.; Fang, F. Association between Diabetes and Amyotrophic Lateral Sclerosis in Sweden. Eur. J. Neurol. 2015, 22, 1436-1442. [CrossRef]

40. Jawaid, A.; Paganoni, S.; Hauser, C.; Schulz, P.E. Trials of Antidiabetic Drugs in Amyotrophic Lateral Sclerosis: Proceed with Caution? Neurodegener. Dis. 2014, 13, 205-208. [CrossRef]

41. Palamiuc, L.; Schlagowski, A.; Ngo, S.T.; Vernay, A.; Dirrig-Grosch, S.; Henriques, A.; Boutillier, A.-L.; Zoll, J.; Echaniz-Laguna, A.; Loeffler, J.-P.; et al. A Metabolic Switch toward Lipid Use in Glycolytic Muscle Is an Early Pathologic Event in a Mouse Model of Amyotrophic Lateral Sclerosis. EMBO Mol. Med. 2015, 7, 526-546. [CrossRef]

42. Miyazaki, K.; Masamoto, K.; Morimoto, N.; Kurata, T.; Mimoto, T.; Obata, T.; Kanno, I.; Abe, K. Early and Progressive Impairment of Spinal Blood Flow-Glucose Metabolism Coupling in Motor Neuron Degeneration of ALS Model Mice. J. Cereb. Blood Flow Metab. 2012, 32, 456-467. [CrossRef]

43. Cistaro, A.; Pagani, M.; Montuschi, A.; Calvo, A.; Moglia, C.; Canosa, A.; Restagno, G.; Brunetti, M.; Traynor, B.J.; Nobili, F.; et al. The Metabolic Signature of C9ORF72-Related ALS: FDG PET Comparison with Nonmutated Patients. Eur. J. Nucl. Med. Mol. Imaging 2014, 41, 844-852. [CrossRef]

44. Ferri, A.; Coccurello, R. What Is "Hyper" in the ALS Hypermetabolism? Mediat. Inflamm. 2017, 2017, 7821672. [CrossRef]

45. Tang, B.L. Glucose, Glycolysis, and Neurodegenerative Diseases. J. Cell. Physiol. 2020, 235, 7653-7662. [CrossRef]

46. Pradat, P.-F.; Bruneteau, G.; Gordon, P.H.; Dupuis, L.; Bonnefont-Rousselot, D.; Simon, D.; Salachas, F.; Corcia, P.; Frochot, V.; Lacorte, J.-M.; et al. Impaired Glucose Tolerance in Patients with Amyotrophic Lateral Sclerosis. Amyotroph. Lateral Scler. 2010, 11, 166-171. [CrossRef]

47. Gustafson, A.; Störtebecker, P. Vascular and Metabolic Studies of Amyotrophic Lateral Sclerosis. II. Lipid and Carbohydrate Metabolism. Neurology 1972, 22, 528-536. [CrossRef] [PubMed] 
48. Dupuis, L.; Corcia, P.; Fergani, A.; Gonzalez De Aguilar, J.L.; Bonnefont-Rousselot, D.; Bittar, R.; Seilhean, D.; Hauw, J.J.; Lacomblez, L.; Loeffler, J.P.; et al. Dyslipidemia Is a Protective Factor in Amyotrophic Lateral Sclerosis. Neurology 2008, 70, 1004-1009. [CrossRef] [PubMed]

49. Chiò, A.; Calvo, A.; Ilardi, A.; Cavallo, E.; Moglia, C.; Mutani, R.; Palmo, A.; Galletti, R.; Marinou, K.; Papetti, L.; et al. Lower Serum Lipid Levels Are Related to Respiratory Impairment in Patients with ALS. Neurology 2009, 73, 1681-1685. [CrossRef] [PubMed]

50. Dorst, J.; Kühnlein, P.; Hendrich, C.; Kassubek, J.; Sperfeld, A.D.; Ludolph, A.C. Patients with Elevated Triglyceride and Cholesterol Serum Levels Have a Prolonged Survival in Amyotrophic Lateral Sclerosis. J. Neurol. 2011, 258, 613-617. [CrossRef] [PubMed]

51. Sutedja, N.A.; van der Schouw, Y.T.; Fischer, K.; Sizoo, E.M.; Huisman, M.H.B.; Veldink, J.H.; Van den Berg, L.H. Beneficial Vascular Risk Profile Is Associated with Amyotrophic Lateral Sclerosis. J. Neurol. Neurosurg. Psychiatry 2011, 82, 638-642. [CrossRef]

52. Paganoni, S.; Deng, J.; Jaffa, M.; Cudkowicz, M.E.; Wills, A.-M. Body Mass Index, Not Dyslipidemia, Is an Independent Predictor of Survival in Amyotrophic Lateral Sclerosis. Muscle Nerve 2011, 44, 20-24. [CrossRef] [PubMed]

53. Ikeda, K.; Hirayama, T.; Takazawa, T.; Kawabe, K.; Iwasaki, Y. Relationships between Disease Progression and Serum Levels of Lipid, Urate, Creatinine and Ferritin in Japanese Patients with Amyotrophic Lateral Sclerosis: A Cross-Sectional Study. Intern. Med. 2012, 51, 1501-1508. [CrossRef]

54. Dedic, S.I.K.; Stevic, Z.; Dedic, V.; Stojanovic, V.R.; Milicev, M.; Lavrnic, D. Is Hyperlipidemia Correlated with Longer Survival in Patients with Amyotrophic Lateral Sclerosis? Neurol. Res. 2012, 34, 576-580. [CrossRef] [PubMed]

55. Yang, J.W.; Kim, S.-M.; Kim, H.-J.; Kim, J.-E.; Park, K.S.; Kim, S.-H.; Lee, K.-W.; Sung, J.-J. Hypolipidemia in Patients with Amyotrophic Lateral Sclerosis: A Possible Gender Difference? J. Clin. Neurol. 2013, 9, 125-129. [CrossRef] [PubMed]

56. Huang, R.; Guo, X.; Chen, X.; Zheng, Z.; Wei, Q.; Cao, B.; Zeng, Y.; Shang, H. The Serum Lipid Profiles of Amyotrophic Lateral Sclerosis Patients: A Study from South-West China and a Meta-Analysis. Amyotroph. Lateral Scler. Front. Degener. 2015, 16, 359-365. [CrossRef] [PubMed]

57. Mandrioli, J.; Rosi, E.; Fini, N.; Fasano, A.; Raggi, S.; Fantuzzi, A.L.; Bedogni, G. Changes in Routine Laboratory Tests and Survival in Amyotrophic Lateral Sclerosis. Neurol. Sci. 2017, 38, 2177-2182. [CrossRef]

58. Delaye, J.B.; Patin, F.; Piver, E.; Bruno, C.; Vasse, M.; Vourc'h, P.; Andres, C.R.; Corcia, P.; Blasco, H. Low IDL-B and High LDL-1 Subfraction Levels in Serum of ALS Patients. J. Neurol. Sci. 2017, 380, 124-127. [CrossRef]

59. Ingre, C.; Chen, L.; Zhan, Y.; Termorshuizen, J.; Yin, L.; Fang, F. Lipids, Apolipoproteins, and Prognosis of Amyotrophic Lateral Sclerosis. Neurology 2020, 94, e1835-e1844. [CrossRef]

60. Després, J.P. Abdominal Obesity as Important Component of Insulin-Resistance Syndrome. Nutrition 1993, 9, 452-459.

61. Marin, B.; Desport, J.C.; Kajeu, P.; Jesus, P.; Nicolaud, B.; Nicol, M.; Preux, P.M.; Couratier, P. Alteration of Nutritional Status at Diagnosis Is a Prognostic Factor for Survival of Amyotrophic Lateral Sclerosis Patients. J. Neurol. Neurosurg. Psychiatry 2011, 82, 628-634. [CrossRef]

62. Desport, J.C.; Preux, P.M.; Bouteloup-Demange, C.; Clavelou, P.; Beaufrère, B.; Bonnet, C.; Couratier, P.P. Validation of Bioelectrical Impedance Analysis in Patients with Amyotrophic Lateral Sclerosis. Am. J. Clin. Nutr. 2003, 77, 1179-1185. [CrossRef]

63. Roubeau, V.; Blasco, H.; Maillot, F.; Corcia, P.; Praline, J. Nutritional Assessment of Amyotrophic Lateral Sclerosis in Routine Practice: Value of Weighing and Bioelectrical Impedance Analysis. Muscle Nerve 2015, 51, 479-484. [CrossRef] [PubMed]

64. Lindauer, E.; Dupuis, L.; Müller, H.-P.; Neumann, H.; Ludolph, A.C.; Kassubek, J. Adipose Tissue Distribution Predicts Survival in Amyotrophic Lateral Sclerosis. PLoS ONE 2013, 8, e67783. [CrossRef]

65. Newhouse, A.; Chemali, Z. Neuroendocrine Disturbances in Neurodegenerative Disorders: A Scoping Review. Psychosomatics 2020, 61, 105-115. [CrossRef]

66. Jawaid, A.; Abid, A.; Schulz, P.E. Diabetes Mellitus and Amyotrophic Lateral Sclerosis: Time to Bridge the Gap between the Bench and the Bedside. Eur. J. Neurol. 2018, 25, 3-4. [CrossRef]

67. De la Monte, S.M. Insulin Resistance and Neurodegeneration: Progress towards the Development of New Therapeutics for Alzheimer's Disease. Drugs 2017, 77, 47-65. [CrossRef] [PubMed]

68. Nathan, D.M.; Davidson, M.B.; DeFronzo, R.A.; Heine, R.J.; Henry, R.R.; Pratley, R.; Zinman, B.; American Diabetes Association. Impaired Fasting Glucose and Impaired Glucose Tolerance: Implications for Care. Diabetes Care 2007, 30, 753-759. [CrossRef]

69. Norhammar, A.; Tenerz, A.; Nilsson, G.; Hamsten, A.; Efendíc, S.; Rydén, L.; Malmberg, K. Glucose Metabolism in Patients with Acute Myocardial Infarction and No Previous Diagnosis of Diabetes Mellitus: A Prospective Study. Lancet 2002, 359, $2140-2144$. [CrossRef]

70. Adibhatla, R.M.; Hatcher, J.F. Role of Lipids in Brain Injury and Diseases. Future Lipidol. 2007, 2, 403-422. [CrossRef] [PubMed]

71. Schmitt, F.; Hussain, G.; Dupuis, L.; Loeffler, J.-P.; Henriques, A. A Plural Role for Lipids in Motor Neuron Diseases: Energy, Signaling and Structure. Front. Cell. Neurosci. 2014, 8, 25. [CrossRef]

72. González De Aguilar, J.-L. Lipid Biomarkers for Amyotrophic Lateral Sclerosis. Front. Neurol. 2019, 10, 284. [CrossRef]

73. Ferrari, R.; Kapogiannis, D.; Huey, E.D.; Momeni, P. FTD and ALS: A Tale of Two Diseases. Curr. Alzheimer Res. 2011, 8, 273-294. [CrossRef] 
74. Ahmed, R.M.; Highton-Williamson, E.; Caga, J.; Thornton, N.; Ramsey, E.; Zoing, M.; Kim, W.S.; Halliday, G.M.; Piguet, O.; Hodges, J.R.; et al. Lipid Metabolism and Survival Across the Frontotemporal Dementia-Amyotrophic Lateral Sclerosis Spectrum: Relationships to Eating Behavior and Cognition. J. Alzheimers Dis. 2018, 61, 773-783. [CrossRef]

75. Bjornevik, K.; O’Reilly, É.J.; Cortese, M.; Furtado, J.D.; Kolonel, L.N.; Le Marchand, L.; Mccullough, M.L.; Paganoni, S.; Schwarzschild, M.A.; Shadyab, A.H.; et al. Pre-Diagnostic Plasma Lipid Levels and the Risk of Amyotrophic Lateral Sclerosis. Amyotroph. Lateral Scler. Front. Degener. 2021, 22, 133-143. [CrossRef]

76. Goldstein, M.R.; Mascitelli, L.; Pezzetta, F. Dyslipidemia Is a Protective Factor in Amyotrophic Lateral Sclerosis. Neurology 2008, 71, 956-957. [CrossRef]

77. Yoshii, Y.; Ikeda, K.; Iwamoto, K.; Kawase, Y.; Iwasaki, Y. Re: Dyslipidemia Is a Protective Factor in Amyotrophic Lateral Sclerosis. Neurology 2009, 72, 944-945. [CrossRef] [PubMed]

78. Rafiq, M.K.; Lee, E.; Bradburn, M.; McDermott, C.J.; Shaw, P.J. Effect of Lipid Profile on Prognosis in the Patients with Amyotrophic Lateral Sclerosis: Insights from the Olesoxime Clinical Trial. Amyotroph. Lateral Scler. Front. Degener. 2015, 16, 1-7. [CrossRef]

79. Duffy, L.M.; Chapman, A.L.; Shaw, P.J.; Grierson, A.J. Review: The Role of Mitochondria in the Pathogenesis of Amyotrophic Lateral Sclerosis. Neuropathol. Appl. Neurobiol. 2011, 37, 336-352. [CrossRef]

80. Manfredi, G.; Kawamata, H. Mitochondria and Endoplasmic Reticulum Crosstalk in Amyotrophic Lateral Sclerosis. Neurobiol. Dis. 2016, 90, 35-42. [CrossRef]

81. Smith, E.F.; Shaw, P.J.; De Vos, K.J. The Role of Mitochondria in Amyotrophic Lateral Sclerosis. Neurosci. Lett. 2019, $710,132933$. [CrossRef]

82. Nakano, Y.; Hirayama, K.; Terao, K. Hepatic Ultrastructural Changes and Liver Dysfunction in Amyotrophic Lateral Sclerosis. Arch. Neurol. 1987, 44, 103-106. [CrossRef]

83. Højlund, K.; Mogensen, M.; Sahlin, K.; Beck-Nielsen, H. Mitochondrial Dysfunction in Type 2 Diabetes and Obesity. Endocrinol. Metab. Clin. N. Am. 2008, 37, 713-731. [CrossRef]

84. Joardar, A.; Manzo, E.; Zarnescu, D.C. Metabolic Dysregulation in Amyotrophic Lateral Sclerosis: Challenges and Opportunities. Curr. Genet. Med. Rep. 2017, 5, 108-114. [CrossRef]

85. Nuttall, F.Q. Body Mass Index: Obesity, BMI, and Health: A Critical Review. Nutr. Today 2015, 50, 117-128. [CrossRef]

86. O’Reilly, É.J.; Wang, M.; Adami, H.-O.; Alonso, A.; Bernstein, L.; van den Brandt, P.; Buring, J.; Daugherty, S.; Deapen, D.; Freedman, D.M.; et al. Prediagnostic Body Size and Risk of Amyotrophic Lateral Sclerosis Death in 10 Studies. Amyotroph. Lateral Scler. Front. Degener. 2018, 19, 396-406. [CrossRef] [PubMed]

87. Gallo, V.; Wark, P.A.; Jenab, M.; Pearce, N.; Brayne, C.; Vermeulen, R.; Andersen, P.M.; Hallmans, G.; Kyrozis, A.; Vanacore, N.; et al. Prediagnostic Body Fat and Risk of Death from Amyotrophic Lateral Sclerosis: The EPIC Cohort. Neurology 2013, 80, 829-838. [CrossRef]

88. O'Reilly, É.J.; Wang, H.; Weisskopf, M.G.; Fitzgerald, K.C.; Falcone, G.; McCullough, M.L.; Thun, M.; Park, Y.; Kolonel, L.N.; Ascherio, A. Premorbid Body Mass Index and Risk of Amyotrophic Lateral Sclerosis. Amyotroph. Lateral Scler. Front. Degener. 2013, 14, 205-211. [CrossRef]

89. Riboli, E.; Hunt, K.J.; Slimani, N.; Ferrari, P.; Norat, T.; Fahey, M.; Charrondière, U.R.; Hémon, B.; Casagrande, C.; Vignat, J.; et al. European Prospective Investigation into Cancer and Nutrition (EPIC): Study Populations and Data Collection. Public Health Nutr. 2002, 5, 1113-1124. [CrossRef]

90. Maselli, R.A.; Wollman, R.L.; Leung, C.; Distad, B.; Palombi, S.; Richman, D.P.; Salazar-Grueso, E.F.; Roos, R.P. Neuromuscular Transmission in Amyotrophic Lateral Sclerosis. Muscle Nerve 1993, 16, 1193-1203. [CrossRef]

91. Kühnlein, P.; Gdynia, H.-J.; Sperfeld, A.-D.; Lindner-Pfleghar, B.; Ludolph, A.C.; Prosiegel, M.; Riecker, A. Diagnosis and Treatment of Bulbar Symptoms in Amyotrophic Lateral Sclerosis. Nat. Clin. Pract. Neurol. 2008, 4, 366-374. [CrossRef] [PubMed]

92. Ngo, S.T.; Steyn, F.J.; McCombe, P.A. Body Mass Index and Dietary Intervention: Implications for Prognosis of Amyotrophic Lateral Sclerosis. J. Neurol. Sci. 2014, 340, 5-12. [CrossRef] [PubMed]

93. Janse van Mantgem, M.R.; van Eijk, R.P.A.; van der Burgh, H.K.; Tan, H.H.G.; Westeneng, H.-J.; van Es, M.A.; Veldink, J.H.; van den Berg, L.H. Prognostic Value of Weight Loss in Patients with Amyotrophic Lateral Sclerosis: A Population-Based Study. J. Neurol. Neurosurg. Psychiatry 2020, 91, 867-875. [CrossRef] [PubMed]

94. Westerterp, K.R. Diet Induced Thermogenesis. Nutr. Metab. 2004, 1, 5. [CrossRef] [PubMed]

95. Kasarskis, E.J.; Mendiondo, M.S.; Matthews, D.E.; Mitsumoto, H.; Tandan, R.; Simmons, Z.; Bromberg, M.B.; Kryscio, R.J.; ALS Nutrition/NIPPV Study Group. Estimating Daily Energy Expenditure in Individuals with Amyotrophic Lateral Sclerosis. Am. J. Clin. Nutr. 2014, 99, 792-803. [CrossRef] [PubMed]

96. Frankenfield, D.C.; Muth, E.R.; Rowe, W.A. The Harris-Benedict Studies of Human Basal Metabolism. J. Am. Diet. Assoc. 1998, 98, 439-445. [CrossRef]

97. Vaisman, N.; Lusaus, M.; Nefussy, B.; Niv, E.; Comaneshter, D.; Hallack, R.; Drory, V.E. Do Patients with Amyotrophic Lateral Sclerosis (ALS) Have Increased Energy Needs? J. Neurol. Sci. 2009, 279, 26-29. [CrossRef]

98. Desport, J.C.; Preux, P.M.; Truong, C.T.; Courat, L.; Vallat, J.M.; Couratier, P. Nutritional Assessment and Survival in ALS Patients. Amyotroph. Lateral Scler. Other Motor Neuron Disord. 2000, 1, 91-96. [CrossRef]

99. Kasarskis, E.J.; Berryman, S.; Vanderleest, J.G.; Schneider, A.R.; McClain, C.J. Nutritional Status of Patients with Amyotrophic Lateral Sclerosis: Relation to the Proximity of Death. Am. J. Clin. Nutr. 1996, 63, 130-137. [CrossRef] 
100. Ellis, A.C.; Rosenfeld, J. Which Equation Best Predicts Energy Expenditure in Amyotrophic Lateral Sclerosis? J. Am. Diet. Assoc. 2011, 111, 1680-1687. [CrossRef]

101. Sherman, M.S.; Pillai, A.; Jackson, A.; Heiman-Patterson, T. Standard Equations Are Not Accurate in Assessing Resting Energy Expenditure in Patients with Amyotrophic Lateral Sclerosis. JPEN J. Parenter. Enter. Nutr. 2004, 28, 442-446. [CrossRef] [PubMed]

102. Genton, L.; Viatte, V.; Janssens, J.P.; Héritier, A.C.; Pichard, C. Nutritional State, Energy Intakes and Energy Expenditure of Amyotrophic Lateral Sclerosis (ALS) Patients. Clin. Nutr. 2011, 30, 553-559. [CrossRef]

103. Desport, J.C.; Preux, P.M.; Magy, L.; Boirie, Y.; Vallat, J.M.; Beaufrère, B.; Couratier, P. Factors Correlated with Hypermetabolism in Patients with Amyotrophic Lateral Sclerosis. Am. J. Clin. Nutr. 2001, 74, 328-334. [CrossRef] [PubMed]

104. Desport, J.-C.; Torny, F.; Lacoste, M.; Preux, P.-M.; Couratier, P. Hypermetabolism in ALS: Correlations with Clinical and Paraclinical Parameters. Neurodegener. Dis. 2005, 2, 202-207. [CrossRef] [PubMed]

105. Funalot, B.; Desport, J.-C.; Sturtz, F.; Camu, W.; Couratier, P. High Metabolic Level in Patients with Familial Amyotrophic Lateral Sclerosis. Amyotroph. Lateral Scler. 2009, 10, 113-117. [CrossRef] [PubMed]

106. Park, Y.; Park, J.; Kim, Y.; Baek, H.; Kim, S.H. Association between Nutritional Status and Disease Severity Using the Amyotrophic Lateral Sclerosis (ALS) Functional Rating Scale in ALS Patients. Nutrition 2015, 31, 1362-1367. [CrossRef]

107. Jésus, P.; Fayemendy, P.; Nicol, M.; Lautrette, G.; Sourisseau, H.; Preux, P.M.; Desport, J.C.; Marin, B.; Couratier, P. Hypermetabolism Is a Deleterious Prognostic Factor in Patients with Amyotrophic Lateral Sclerosis. Eur. J. Neurol. 2018, 25, 97-104. [CrossRef] [PubMed]

108. Lee, J.; Baek, H.; Kim, S.H.; Park, Y. Association between Estimated Total Daily Energy Expenditure and Stage of Amyotrophic Lateral Sclerosis. Nutrition 2017, 33, 181-186. [CrossRef]

109. Steyn, F.J.; Ioannides, Z.A.; van Eijk, R.P.A.; Heggie, S.; Thorpe, K.A.; Ceslis, A.; Heshmat, S.; Henders, A.K.; Wray, N.R.; van den Berg, L.H.; et al. Hypermetabolism in ALS Is Associated with Greater Functional Decline and Shorter Survival. J. Neurol. Neurosurg. Psychiatry 2018, 89, 1016-1023. [CrossRef]

110. Bouteloup, C.; Desport, J.C.; Clavelou, P.; Guy, N.; Derumeaux-Burel, H.; Ferrier, A.; Couratier, P. Hypermetabolism in ALS Patients: An Early and Persistent Phenomenon. J. Neurol. 2009, 256, 1236-1242. [CrossRef]

111. Bachman, E.S.; Dhillon, H.; Zhang, C.-Y.; Cinti, S.; Bianco, A.C.; Kobilka, B.K.; Lowell, B.B. BetaAR Signaling Required for Diet-Induced Thermogenesis and Obesity Resistance. Science 2002, 297, 843-845. [CrossRef] [PubMed]

112. Baltadzhieva, R.; Gurevich, T.; Korczyn, A.D. Autonomic Impairment in Amyotrophic Lateral Sclerosis. Curr. Opin. Neurol. 2005, 18, 487-493. [CrossRef] [PubMed]

113. Muscaritoli, M.; Kushta, I.; Molfino, A.; Inghilleri, M.; Sabatelli, M.; Rossi Fanelli, F. Nutritional and Metabolic Support in Patients with Amyotrophic Lateral Sclerosis. Nutrition 2012, 28, 959-966. [CrossRef] [PubMed]

114. Dupuis, L.; Oudart, H.; René, F.; Gonzalez de Aguilar, J.-L.; Loeffler, J.-P. Evidence for Defective Energy Homeostasis in Amyotrophic Lateral Sclerosis: Benefit of a High-Energy Diet in a Transgenic Mouse Model. Proc. Natl. Acad. Sci. USA 2004, 101, 11159-11164. [CrossRef]

115. Fergani, A.; Oudart, H.; Gonzalez De Aguilar, J.-L.; Fricker, B.; René, F.; Hocquette, J.-F.; Meininger, V.; Dupuis, L.; Loeffler, J.-P. Increased Peripheral Lipid Clearance in an Animal Model of Amyotrophic Lateral Sclerosis. J. Lipid Res. 2007, 48, 1571-1580. [CrossRef]

116. Menzies, F.M.; Ince, P.G.; Shaw, P.J. Mitochondrial Involvement in Amyotrophic Lateral Sclerosis. Neurochem. Int. 2002, 40, 543-551. [CrossRef]

117. Dodge, J.C.; Treleaven, C.M.; Fidler, J.A.; Tamsett, T.J.; Bao, C.; Searles, M.; Taksir, T.V.; Misra, K.; Sidman, R.L.; Cheng, S.H.; et al. Metabolic Signatures of Amyotrophic Lateral Sclerosis Reveal Insights into Disease Pathogenesis. Proc. Natl. Acad. Sci. USA 2013, 110, 10812-10817. [CrossRef]

118. Konrad, C.; Kawamata, H.; Bredvik, K.G.; Arreguin, A.J.; Cajamarca, S.A.; Hupf, J.C.; Ravits, J.M.; Miller, T.M.; Maragakis, N.J.; Hales, C.M.; et al. Fibroblast Bioenergetics to Classify Amyotrophic Lateral Sclerosis Patients. Mol. Neurodegener. 2017, 12, 76. [CrossRef]

119. Kirk, K.; Gennings, C.; Hupf, J.C.; Tadesse, S.; D’Aurelio, M.; Kawamata, H.; Valsecchi, F.; Mitsumoto, H.; ALS/PLS COSMOS Study Groups; Manfredi, G. Bioenergetic Markers in Skin Fibroblasts of Sporadic Amyotrophic Lateral Sclerosis and Progressive Lateral Sclerosis Patients. Ann. Neurol. 2014, 76, 620-624. [CrossRef] [PubMed]

120. Marshall, W.J. Nutritional Assessment: Its Role in the Provision of Nutritional Support. J. Clin. Pathol. 2008, 61, 1083-1088. [CrossRef]

121. Evans, W.J.; Morley, J.E.; Argilés, J.; Bales, C.; Baracos, V.; Guttridge, D.; Jatoi, A.; Kalantar-Zadeh, K.; Lochs, H.; Mantovani, G.; et al. Cachexia: A New Definition. Clin. Nutr. 2008, 27, 793-799. [CrossRef] [PubMed]

122. Piquet, M.A. Nutritional Approach for Patients with Amyotrophic Lateral Sclerosis. Rev. Neurol. 2006, 162, 4 S177-4S187. [CrossRef]

123. Desport, J.C.; Preux, P.M.; Truong, T.C.; Vallat, J.M.; Sautereau, D.; Couratier, P. Nutritional Status Is a Prognostic Factor for Survival in ALS Patients. Neurology 1999, 53, 1059-1063. [CrossRef] [PubMed]

124. Jawaid, A.; Murthy, S.B.; Wilson, A.M.; Qureshi, S.U.; Amro, M.J.; Wheaton, M.; Simpson, E.; Harati, Y.; Strutt, A.M.; York, M.K.; et al. A Decrease in Body Mass Index Is Associated with Faster Progression of Motor Symptoms and Shorter Survival in ALS. Amyotroph. Lateral Scler. 2010, 11, 542-548. [CrossRef] 
125. Marin, B.; Arcuti, S.; Jesus, P.; Logroscino, G.; Copetti, M.; Fontana, A.; Nicol, M.; Raymondeau, M.; Desport, J.C.; Preux, P.M.; et al. Population-Based Evidence That Survival in Amyotrophic Lateral Sclerosis Is Related to Weight Loss at Diagnosis. Neurodegener. Dis. 2016, 16, 225-234. [CrossRef]

126. Limousin, N.; Blasco, H.; Corcia, P.; Gordon, P.H.; De Toffol, B.; Andres, C.; Praline, J. Malnutrition at the Time of Diagnosis Is Associated with a Shorter Disease Duration in ALS. J. Neurol. Sci. 2010, 297, 36-39. [CrossRef] [PubMed]

127. Jesus, P.; Massoulard, A.; Marin, B.; Nicol, M.; Laplagne, O.; Baptiste, A.; Gindre-Poulvelarie, L.; Couratier, P.; Fraysse, J.L.; Desport, J.C. First Assessment at Home of Amyotrophic Lateral Sclerosis (ALS) Patients by a Nutrition Network in the French Region of Limousin. Amyotroph. Lateral Scler. 2012, 13, 538-543. [CrossRef]

128. Petzold, G.C.; Einhäupl, K.M.; Valdueza, J.M. Persistent Bitter Taste as an Initial Symptom of Amyotrophic Lateral Sclerosis. J. Neurol. Neurosurg. Psychiatr. 2003, 74, 687-688. [CrossRef]

129. Hardiman, O.; van den Berg, L.H.; Kiernan, M.C. Clinical Diagnosis and Management of Amyotrophic Lateral Sclerosis. Nat. Rev. Neurol. 2011, 7, 639-649. [CrossRef]

130. Fitzgerald, K.C.; O’Reilly, É.J.; Falcone, G.J.; McCullough, M.L.; Park, Y.; Kolonel, L.N.; Ascherio, A. Dietary w-3 Polyunsaturated Fatty Acid Intake and Risk for Amyotrophic Lateral Sclerosis. JAMA Neurol. 2014, 71, 1102-1110. [CrossRef]

131. Zhang, W.; Li, P.; Hu, X.; Zhang, F.; Chen, J.; Gao, Y. Omega-3 Polyunsaturated Fatty Acids in the Brain: Metabolism and Neuroprotection. Front. Biosci. 2011, 16, 2653-2670. [CrossRef]

132. Nelson, L.M.; Matkin, C.; Longstreth, W.T.; McGuire, V. Population-Based Case-Control Study of Amyotrophic Lateral Sclerosis in Western Washington State. II. Diet. Am. J. Epidemiol. 2000, 151, 164-173. [CrossRef] [PubMed]

133. Morozova, N.; Weisskopf, M.G.; McCullough, M.L.; Munger, K.L.; Calle, E.E.; Thun, M.J.; Ascherio, A. Diet and Amyotrophic Lateral Sclerosis. Epidemiology 2008, 19, 324-337. [CrossRef] [PubMed]

134. Huisman, M.H.B.; Seelen, M.; van Doormaal, P.T.C.; de Jong, S.W.; de Vries, J.H.M.; van der Kooi, A.J.; de Visser, M.; Schelhaas, H.J.; van den Berg, L.H.; Veldink, J.H. Effect of Presymptomatic Body Mass Index and Consumption of Fat and Alcohol on Amyotrophic Lateral Sclerosis. JAMA Neurol. 2015, 72, 1155-1162. [CrossRef] [PubMed]

135. Pupillo, E.; Bianchi, E.; Chiò, A.; Casale, F.; Zecca, C.; Tortelli, R.; Beghi, E.; SLALOM Group; PARALS Group; SLAP Group. Amyotrophic Lateral Sclerosis and Food Intake. Amyotroph. Lateral Scler. Front. Degener. 2018, 19, 267-274. [CrossRef]

136. Okamoto, K.; Kihira, T.; Kondo, T.; Kobashi, G.; Washio, M.; Sasaki, S.; Yokoyama, T.; Miyake, Y.; Sakamoto, N.; Inaba, Y.; et al. Nutritional Status and Risk of Amyotrophic Lateral Sclerosis in Japan. Amyotroph. Lateral Scler. 2007, 8, 300-304. [CrossRef] [PubMed]

137. Veldink, J.H.; Kalmijn, S.; Groeneveld, G.J.; Wunderink, W.; Koster, A.; de Vries, J.H.M.; van der Luyt, J.; Wokke, J.H.J.; Van den Berg, L.H. Intake of Polyunsaturated Fatty Acids and Vitamin E Reduces the Risk of Developing Amyotrophic Lateral Sclerosis. J. Neurol. Neurosurg. Psychiatry 2007, 78, 367-371. [CrossRef]

138. Ascherio, A.; Weisskopf, M.G.; O'reilly, E.J.; Jacobs, E.J.; McCullough, M.L.; Calle, E.E.; Cudkowicz, M.; Thun, M.J. Vitamin E Intake and Risk of Amyotrophic Lateral Sclerosis. Ann. Neurol. 2005, 57, 104-110. [CrossRef] [PubMed]

139. Longnecker, M.P.; Kamel, F.; Umbach, D.M.; Munsat, T.L.; Shefner, J.M.; Lansdell, L.W.; Sandler, D.P. Dietary Intake of Calcium, Magnesium and Antioxidants in Relation to Risk of Amyotrophic Lateral Sclerosis. Neuroepidemiology 2000, 19, 210-216. [CrossRef]

140. Okamoto, K.; Kihira, T.; Kobashi, G.; Washio, M.; Sasaki, S.; Yokoyama, T.; Miyake, Y.; Sakamoto, N.; Inaba, Y.; Nagai, M. Fruit and Vegetable Intake and Risk of Amyotrophic Lateral Sclerosis in Japan. Neuroepidemiology 2009, 32, 251-256. [CrossRef] [PubMed]

141. Wang, H.; O’Reilly, É.J.; Weisskopf, M.G.; Logroscino, G.; McCullough, M.L.; Schatzkin, A.; Kolonel, L.N.; Ascherio, A. Vitamin E Intake and Risk of Amyotrophic Lateral Sclerosis: A Pooled Analysis of Data from 5 Prospective Cohort Studies. Am. J. Epidemiol. 2011, 173, 595-602. [CrossRef]

142. Fitzgerald, K.C.; O’Reilly, É.J.; Fondell, E.; Falcone, G.J.; McCullough, M.L.; Park, Y.; Kolonel, L.N.; Ascherio, A. Intakes of Vitamin $\mathrm{C}$ and Carotenoids and Risk of Amyotrophic Lateral Sclerosis: Pooled Results from 5 Cohort Studies. Ann. Neurol. 2013, 73, 236-245. [CrossRef] [PubMed]

143. Fondell, E.; O’Reilly, E.J.; Fitzgerald, K.C.; Falcone, G.J.; McCullough, M.L.; Park, Y.; Kolonel, L.N.; Ascherio, A. Magnesium Intake and Risk of Amyotrophic Lateral Sclerosis: Results from Five Large Cohort Studies. Amyotroph. Lateral Scler. Front. Degener. 2013, 14, 356-361. [CrossRef] [PubMed]

144. Nieves, J.W.; Gennings, C.; Factor-Litvak, P.; Hupf, J.; Singleton, J.; Sharf, V.; Oskarsson, B.; Fernandes Filho, J.A.M.; Sorenson, E.J.; D'Amico, E.; et al. Association between Dietary Intake and Function in Amyotrophic Lateral Sclerosis. JAMA Neurol. 2016, 73, 1425-1432. [CrossRef] [PubMed]

145. Kim, B.; Jin, Y.; Kim, S.H.; Park, Y. Association between Macronutrient Intake and Amyotrophic Lateral Sclerosis Prognosis. Nutr. Neurosci. 2020, 23, 8-15. [CrossRef] [PubMed]

146. Rock, C.L.; Jacob, R.A.; Bowen, P.E. Update on the Biological Characteristics of the Antioxidant Micronutrients: Vitamin C, Vitamin E, and the Carotenoids. J. Am. Diet. Assoc. 1996, 96, 693-702; quiz 703. [CrossRef]

147. Barber, S.C.; Shaw, P.J. Oxidative Stress in ALS: Key Role in Motor Neuron Injury and Therapeutic Target. Free Radic. Biol. Med. 2010, 48, 629-641. [CrossRef]

148. D'Amico, E.; Factor-Litvak, P.; Santella, R.M.; Mitsumoto, H. Clinical Perspective on Oxidative Stress in Sporadic Amyotrophic Lateral Sclerosis. Free Radic. Biol. Med. 2013, 65, 509-527. [CrossRef] [PubMed]

149. Tourniaire, F.; Gouranton, E.; von Lintig, J.; Keijer, J.; Bonet, M.L.; Amengual, J.; Lietz, G.; Landrier, J.-F. Beta-Carotene Conversion Products and Their Effects on Adipose Tissue. Genes Nutr. 2009, 4, 179-187. [CrossRef] 